\title{
PERAN MAJELIS ADAT ACEH DALAM MENYELESAIKAN SENGKETA WARIS TANAH DI KECAMATAN TEMPUK TEUNGOH KOTA LHOKSEUMAWE
}

\author{
Ucha Hadi Putri ${ }^{1)}$, Yaswirman, Syahrial Razak ${ }^{2}$ \\ Program Magister Kenotariatan, Universitas Andalas, \\ Jl. Adi Sucipto Gg. Amal No. 81 Pekanbaru, \\ email: uchahp@gmail.com \\ Nomor HP: 082390002629
}

\begin{abstract}
There are three inheritance law systems in Indonesia, namely the Islamic inheritance system, the customary inheritance law system and the civil inheritance system. Inheritance law of a group of people is strongly influenced by the kinship form of the community itself. The Acehnese adheres to the parental kinship system, which means the inheritance system in providing the position of boys and girls, who both have the opportunity to become heirs. The kinship system in the parental community is based on both parents. Based on Law Number 40 of 1999 concerning the Privileges of Aceh in Article 3 paragraph 2, affirms that Aceh is a Special Region in the fields of custom, religion and education. The government provides space for local communities to revive existing customs in society, one of which is in the settlement of inheritance disputes resolved by the Majelis Adat Aceh (MAA). The author is interested in conducting research on the role of MAA in resolving disputes of land inheritance in the subdistrict of teungoh sub-district in lhokseumawe city, writing theses using empirical juridical methods which in reality in the field are associated with the legal aspects or legislation in force. The role of the MAA in resolving inheritance disputes has not been fully implemented, from the administrative system and the application of decisions from the MAA which are detrimental to the parties.
\end{abstract}

Keywords: Role, Majelis Adat Aceh, Inheritance Dispute

\begin{abstract}
Abstrak
Sistem hukum waris yang berlaku di Indonesia ada tiga yaitu, sistem Hukum waris Islam, sistem hukum waris Adat dan sistem hukum waris Perdata. Hukum waris suatu golongan masyarakat sangat dipengaruhi oleh bentuk kekerabatan dari masyarakat itu sendiri. Masyarakat Aceh menganut sistem kekerabatan parental artinya sistem waris dalam memberikan kedudukan anak laki-laki dan anak perempuan yaitu sama-sama mempunyai peluang untuk menjadi ahli waris. Sistem kekerabatan pada masyarakat parental didasarkan pada kedua orang tua. Berdasarkan Undang-Undang Nomor 40 Tahun 1999 Tentang Keistimewaan Aceh pada Pasal 3 ayat 2, menegaskan bahwa Aceh adalah Daerah Istimewa dalam bidang adat, agama, dan pendidikan. Pemerintah memberikan ruang bagi masyarakat lokal untuk bangkit kembali adat yang ada dalam masyarakat, salah satunya dalam penyelesaian sengketa waris yang diselesaikan oleh Majelis adat Aceh. Penulis tertarik untuk melakukan penelitian tentang peran MAA dalam menyelesaikan sengketa waris tanah di kecamatan tempuk teungoh kota lhokseumawe, penulisan tesis menggunakan metode yuridis empiris yang pada kenyataan di lapangan dikaitkan dengan aspek hukum atau perundang-undangan yang berlaku. Peran MAA dalam menyelesaikan sengketa waris belum sepenuhnya berjalan dengan baik, dari sistem administrasi maupun penerapan keputusan dari MAA.
\end{abstract}

Kata Kunci : Peran, Majelis Adat Aceh, Sengketa Waris

1. Mahasiswa Prodi Magister Kenotariatan Fakultas Hukum Universitas Andalas

2. Dosen Fakultas Hukum Universitas Andalas 


\section{PENDAHULUAN}

Sistem hukum waris yang berlaku di Indonesia ada 3 (tiga) yaitu, sistem Hukum waris Islam, sistem hukum waris Adat dan sistem hukum waris Perdata. Ketiga sistem ini semua berlaku dikalangan masyarakat hukum di Indonesia. Terserah para pihak untuk memilih hukum apa yang akan digunakan dalam pembagian harta warisan yang dipandang cocok dan mencerminkan rasa keadilan. ${ }^{3}$

Hukum adat tersusun dan terbangun atas nilai, kaidah, dan norma yang disepakati dan diyakini kebenarannya oleh komunitas masyarakat adat. ${ }^{4}$ Hukum adat sebagai hukum yang hidup dikonsepsikan sebagai suatu sistem hukum yang terbentuk dan berasal dari pengalaman empiris masyarakat pada masa lalu, yang dianggap adil dan patut dan telah mendapatkan legitimasi dari penguasa adat sehingga mengikat atau wajib dipatuhi (bersifat normatif). ${ }^{5}$

Proses pewarisan menurut hukum waris adat pada tiap daerah berbeda beda. Masyarakat Indonesia yang berbhineka terdiri dari beragam suku bangsa memiliki adat istiadat dan hukum adat yang beragam antara yang satu dengan yang lainnya berbeda. Hukum waris suatu golongan masyarakat sangat dipengaruhi oleh bentuk kekerabatan dari masyarakat itu sendiri, setiap kekerabatan atau kekeluargaan memiliki sistem hukum waris sendiri-sendiri.

"Seperti diungkapkan oleh Hilman Hadikusuma bahwa dilihat dari orang yang mendapatkan warisan (kewarisan) di Indonesia terdapat tiga macam sistem, yaitu sistem kewarisan kolektif, kewarisan mayorat, dan kewarisan individual. Di antara ketiga sistem kewarisan tesebut pada kenyataannya ada yang bersifat campuran".

Aceh merupakan salah satu provinsi yang bersifat istimewa dan diberi kewenangan khusus untuk mengatur dan mengurus sendiri urusan pemerintahan dan kepentingan masyarakat setempat sesuai dengan peraturan perundang-undangan yang berlaku. Aceh memberlakukan hukum islam dan hukum adat dalam kehidupan sehari-hari karena adat merupakan salah satu bagian terpenting yang tidak bisa dipisahkan dalam kehidupan masyarakat.

Masyarakat Aceh menganut sistem kekerabatan parental atau bilateral artinya sistem waris dalam masyarakat kekerabatan parental atau bilateral memberikan kedudukan anak laki-laki dan anak perempuan yaitu sama-sama mempunyai peluang untuk menjadi ahli waris. Sistem kekerabatan pada masyarakat parental atau bilateral didasarkan pada kedua orang tua (bapak dan ibu). ${ }^{6}$

Aceh adalah tempat pertama masuknya agama Islam di Indonesia dan sebagai tempat timbulnya kerajaan Islam pertama di Indonesia, yaitu Peurelak dan Pasai. Puncak kejayaan Aceh dicapai pada permulaan abad ke-17, masa pemerintahan Sultan Iskandar Muda. Pada masa Sultan Iskandar Muda agama dan Kebudayaan Islam begitu besar

3. Emman Suparman, Hukum Waris Islam, Rajawali Press, Bandung, 2005, hal. 12

4. Syahrizal Abbas, 2009, Mediasi Dalam hukum syariah, hukum adat, dan hukum nasional, Kencana Prenada Media Group, Jakarta,hal. 235.

5. Otje Salman Soemadiningrat, 2002, Rekonseptualisasi Hukum Adat Kontemporer, Bandung: Alumni, hal. 27.

6. Ibid. 
dalam kehidupan sehari-hari masyarakat Aceh, sehingga daerah ini mendapat julukan "seuramo mekkah" (serambi mekkah). ${ }^{7}$

Pelaksanaan hukum adat tersebut berjalan tertib karena adanya kerjasama yang solid antara pemerintah, lembaga adat dan masyarakat. Salah satunya termasuk aspek penataan hukum adat. Hukum adat Aceh sangat dikenal di seluruh dunia, ada beberapa faktor yang menyebabkan adat Aceh terkenal ke seluruh negeri:

a. Hubungan diplomatis yang sangat erat dengan pemerintah Turki. Hasil dari hubungan bilateral ini Sultan sering berbagi pengalaman tentang kondisi kemajuan di Aceh, termasuk adat-istiadatnya.

b. Luasnya daerah yang berhasil ditaklukkan oleh Kerajaan Aceh. Daerah yang berhasil ditaklukkan sebagian besar adalah daerah-daerah Melayu. Misi Sultan adalah menyebarluaskan agama Islam dan juga memperkenalkan adat-istiadat Aceh. Secara tidak langsung, daerah yang berhasil ditaklukkan harus mengikuti aturan Kerajaan Aceh. ${ }^{8}$

Kepiawaian Sultan Iskandar Muda juga tergambar jelas ketika berhasil mempersatukan beberapa suku yang masih menganut adat budaya masing-masing menjadi adat nasional (hukum adat yang dikendalikan oleh kerajaan). Sebelum Sultan Iskandar Muda memimpin, di Aceh tersebar empat suku besar, yaitu :

1. Suku Lhee Reutoh (Tiga ratus), yang berasal dari orang-orang mante dan Karo/Batak

2. Suku Imuem Peut (Imam Empat), yang berasal dari orang-orang Hindu

3. Suku Tok Batee, kaum asing yang berasal dari Arab, Parsi, Turki, dan Hindi yang sudah lama menetap di Aceh

4. Suku Ja Sandang, yaitu kaum Hindu, tukang tuak yang pertama sekali datang ke Lampanaih. ${ }^{9}$

Beberapa nasehat dari mufti kerajaan dan ahli-ahli agama, maka Sultan telah dapat menyatukan suku-suku yang berbeda tersebut dalam satu wadah pemerintahan. Muncul lah hadih maja yang masih dikenal sampai sekarang yaitu,

"adat bak Poteu Meureuhom, hukom bak Syiah Kuala, kanun bak Putroe Phang, reusam bak Laksamana, hukom ngon adat lage zat ngon, yang artinya adat bersumber pada kebijakansanaan sri sultan dan penasihatnya yang dalam hal ini dilambangkan kepada sultan iskandar muda, hukum merupakan wewenang para ulama yang dalam hal ini dilambangkan oleh ulama besar yang terkenal teungku syiah kuala, urusan kanun seperti kitab sopan santun didalam perkawinan dan lain-lain diserahkan menjadi urusan Maharani yang dilambangkan Putro Phang, urusan reusam menjadi kewenangan panglima kaum dan bentara-bentara di masing-masing tempat atau negeri, hukum dan adat berjalin erat seperti zat dengan sifat." 10

Secara teoritis, masyarakat Indonesia sekalipun ia beragama Islam, masih banyak dalam melaksanakan hukum waris dipengaruhi oleh hukum adat masing-masing yang

7. Ahmad fazil, http://acehseuramoemekkah.blogspot.com/2013/07/sejarah-singkataceh.html, dilihat pada tanggal 11 April 2018 Pukul 13.05 WIB.

8. Ibid.

9. Ibid.

10. Hamid Sarong, 2015, Mahkamah Syari'ah Aceh Lintas Sejarah dan eksistensinya, Global education institute, Banda Aceh, hal. 25. 
masih hidup dan berkembang dalam kehidupan sehari-hari, sehingga terjadi pencampuran antara hukum Islam dan hukum adat dalam menyelesaikan persoalan warisan.

Ketentuan Hukum adat di Aceh, segala harta warisan dibagi-bagikan menurut hukum Islam yang dibarengi oleh Adat, tidak menurut hukum semata-mata atau menurut adat semata-mata. ${ }^{11}$ Semua anak, baik anak laki-laki maupun anak perempuan mempunyai hak yang sama atas harta peninggalan ibu dan bapaknya yaitu dengan membagikan atau mempersamakan hak waris anak laki-laki dan anak perempuan yang didasarkan atas kesepakatan ahli waris, saling rela atau saling terima bagian (tameu jeut-jeut). ${ }^{12}$

Didalam hukum adat Aceh terdapat juga perpaduan antara hukum adat dengan hukum islam yang terasa sangat kental pada kehidupan sehari-hari masyarakat Aceh secara umum dan hal ini juga diterapkan atau dijalankan dalam sistem kewarisan masyarakat Aceh. Dalam realitas kehidupan masyarakat sering ditemui penyelesian sengketa atau perkara diluar pengadilan. Salah satu mekanisme penyelesaian sengketa di luar pengadilan adalah melelui pendekatan adat. Penyelesaian melalui pendekatan adat adalah penyelesian sengketa dengan mekanisme adat dan oleh lembaga adat.

Dilahirkannya Undang-Undang Nomor 40 Tahun 1999 Tentang Keistimewaan Aceh pada Pasal 3 ayat 2, yang menegaskan kembali bahwa Aceh adalah Daerah Istimewa dalam bidang adat, agama, dan pendidikan. Berdasarkan undang-undang ini pemerintah memberikan ruang bagi masyarakat adat lokal untuk bangkit dan menenun kembali adat yang ada dalam masyarakat Aceh. ${ }^{13}$

Status keistimewaan Aceh dikonfirmasikan dengan keluarnya Undang-Undang Nomor 18 Tahun 2001 Tentang Otonomi Khusus bagi Provinsi Daerah Istimewa Aceh sebagai Provinsi Nanggroe Aceh Darussalam (disingkat NAD). Kebijakan ini menyebabkan lahirnya tiga lembaga baru di Aceh, yaitu Majelis Adat Aceh (MAA) yang bertugas mengurus masalah adat, Majelis Permusyawaratan Ulama (MPU) yang bertugas membidangi masalah agama Islam dan Majelis Pendidikan Aceh (MPD) yang mengurus masalah pendidikan di Aceh. ${ }^{14}$

Berdasarkan Undang-Undang Nomor 18 Tahun 2001 tentang Otonomi Khusus khususnya bagi Provinsi Daerah Istimewa Aceh sebagai Provinsi Nanggroe Aceh Darussalam terkait masalah kewarisandapat dijelaskan salah satunya bahwa dalam suatu permasalahan itu diselesaikan melalui majelis Mahkamah Syari'ah Provinsi Nanggroe Aceh Darussalam adalah lembaga peradilan yang bebas dari pengaruh pihak manapun dalam wilayah Provinsi Nanggroe Aceh Darussalam.

Hukum Negara Indonesia sudah ada kompilasi Hukum Islam dan salah satu daerah yang penyelesaian perkaranya berdasarkan Kompilasi Hukum Islam itu adalah daerah Aceh, namun masyarakat Aceh, khususnya didaerah Tempok Teungoh Kota Lhokseumawe, berdasarkan penelitian penulis lakukan dominan penyelesaian pembagian

11. Moehammad Hoesin, 1970, Adat aceh, Dinas Pendidikan Kebudayaan Propinsi Daeerah Istimewa Aceh, Banda Aceh, hal. 163

12. Hasil Wawancara dengan Teungku Yusdedi, Ketua Majelis Adat Aceh Lhokseumawe, Tanggal 29 Maret 2018, Pukul 09.45 WIB.

13. Juniarti, Peran Strategis Peradilan Adat Aceh Dalam Memberikan Keadilan Bagi Perempuan Dan Kaum Marjinal, Badan Litbang Pusat Analisis Perubahan Sosial (PASPAS) Aceh, hal. 5.

14. Rahmat Fitrah, lembaga adat aceh sebagai tempat menyelesaikan sengketa pembagian warisanhttps://media.neliti.com/media/publications/164922-ID-efektifitas-penyelesaian-sengketawarisan.pdf, diakses tanggal 28 Februari 2017. 
warisan tidak diselesaikan di Mahkamah Syari'ah yang berdasarkan Kompilasi hukum Islam akan tetapi lebih dominan diselesaikan melalui Peradilan adat atau MAA. ${ }^{15}$ Penulis memilih penelitian di Kecamatan Tempok Teungoh, Kota Lhokseumawe karena Sengketa pembagian warisan tanah yang diselesaikan secara adat di tingkat Gampong khususnya di Kecamatan Tempok Teungoh Kota Lhokseumawe menggambarkan bahwa para ahli waris lebih memilih dengan jalan damai melalui mediasi yang melibatkan lembaga adat di tingkat gampong daripada diselesaikan melalui Mahkamah Syari'ah yang berdasarkan Kompilasi Hukum Islam.

\section{METODE PENELITIAN}

Pendekatan masalah yang hendak dipergunakan dalam penelitian ini adalah pendekatan yuridis empiris yang artinya prosedur yang dipergunakan untuk memecahkan masalah penelitian dengan meneliti data sekunder terlebih dahulu untuk kemudian dilanjutkan dengan mengadakan penelitian terhadap data primer di lapangan, khususnya mempelajari dan meneliti perihal "Peran Majelis Adat Aceh Dalam Menyelesaikan Sengketa Waris Tanah di Kecamatan Tempuk Teungoh Kota Lhokseumawe".

Penelitian ini bersifat deskriptif kualitatif, yaitu suatu bentuk penelitian yang bertujuan untuk mendapatkan kebenaran yang dibangun atas dasar teori-teori yang berkembang dari penelitian dan terkontrol atas dasar empirik yang mempelajari masalahmasalah yang ada serta tata cara kerja yang berlaku. Penelitian deskriptif kualitatif ini bertujuan untuk mendeskripsikan mengenai peran Majelis Adat Aceh dalam menyelesaikan sengketa waris tanah di kecamatan tempuk teungoh kota lhokseumawe.

Jenis data : a. Data Primer yaitu data yang diperoleh secara langsung dari lokasi penelitian (field research). Data tersebut berupa hasil wawancara dengan Ketua dan anggota Majelis Adat Aceh Kota Lhokseumawe dan didukung oleh : 1) Hasil wawancara dengan Ketua Majelis Adat Aceh. 2) Hasil wawancara dengan Pejabat yang berwenang Pada Kantor Gampong Tempok Teungoh. a. Data sekunder yaitu data yang diperoleh dari bahan pustaka (data kepustakan).

Bahan hukum yang digunakan untuk memperoleh data-data yang berhubungan dalam penelitian adalah. a. Bahan Hukum primer yang dipergunakan yaitu peraturan Perundang-undangan yang mempunyai relevansi dengan judul yang peneliti pilih dan peraturan lain yang menunjang kelengkapan tulisan ini. b. Bahan Hukum Sekunder adalah bahan hukum yang memberikan informasi yang berkaitan dengan isi bahan hukum primer serta implementasinya. c. Bahan Hukum Tersier adalah bahan hukum yang memberi petunjuk maupun penjelasan terhadap bahan hukum primer dan bahan hukum sekunder, seperti kamus dan internet.

15. Abdurrahaman, 2009, Peradilan Adat di Aceh sebagai Sarana Kerukunan Masyarakat (Banda Aceh: Majelis Adat Aceh (MAA) Provinsi Aceh), hal. 1. 


\section{Hasil Penelitian dan Pembahasan}

\section{A. Peran Majelis Adat Aceh dalam menyelesaikan sengketa waris Tanah di Kecamatan Tempuk Teungoh Kota Lhokseumawe}

Pada tahun 2001 Kota Lhokseumawe dimekar menjadi 4 Kecamatan, 9 kemukiman, 68 gampong, dan 259 dusun dan Lhokseumawe ini didominasi oleh suku Aceh, namun terdapat juga suku lainnya seperti Minang, Jawa dan Batak. ${ }^{16}$ Berdasarkan Pasal 1 ayat 5 Peraturan Daerah Nomor 7 tahun 2000 tentang Penyelenggaraan Kehidupan Adat, disebutkan bahwa Lembaga Adat adalah suatu organisasi kemasyarakatan adat yang dibentuk oleh suatu masyarakat hukum adat tertentu, mempunyai wilayah tertentu dan harta kekayaan sendiri serta berhak dan berwenang untuk mengatur dan mengurus serta menyelesaikan hal-hal yang berkaitan dengan adat Aceh.

Berdasarkan ketentuan dalam Pasal 18 Ayat 2 UUD 1945 menyebutkan bahwa "Pemerintah daerah provinsi, daerah kabupaten/kota mengatur dan mengurus sendiri urusan pemerintahan menurut asas otonomi dan tugas pembantuan". Selanjutnya disebutkan dalam Pasal 18B Ayat 1 dan Ayat 2 yang menyebutkan bahwa negara mengakui dan menghormati satuan-satuan pemerintahan daerah yang bersifat khusus dan istimewa, serta menghormati satuan masyarakat hukum adat beserta hak-hak tradisionalnya.

Aparat penegak hukum memberi kesempatan terlebih dahulu kepada geuchik dan imeum mukim untuk menyelesaikan sengeketa-sengketa/perselisihan di gampong/mukim masing-masing. ${ }^{17}$ Sejak zaman Iskandar Muda, semua sengketa, baik itu perdata maupun pidana selalu menempuh prosedur penyelesaian melalui lembaga hukum adat, misalnya warisan, perkelahian, pembunuhan bahkan untuk sekarang ini, kecelakaan lalu lintas di jalan raya penanganannya dilakukan melalui geuchik atau orang tua gampong yang dilakukan di meunasah. Dengan demikian maka berbagai kasus tersebut biasa diselesaikan dengan cepat, sederhana dan murah serta hasil keputusannya akan membentuk kembali jalinan persaudaraan dan kedamaian. ${ }^{18}$

Secara yuridis telah dikenal ada dua cara penyelesaian perkara, pertama penyelesaian perkara secara litigasi yaitu dipengadilan, dan kedua yang dikenal dengan cara non litigasi yaitu penyelesaian sengketa diluar pengadilan. Dengan adanya penyelesaian sengketa alternatif seperti non litigasi, maka pengadilan hanya dijadikan sebagai pilihan yang terakhir oleh para pihak yang menyelesaikan sengketa.

Daerah Lhokseumawe khususnya di daerah Tempok Teungoh sengketa dalam kalangan masyarakat lebih dominan diselesaikan melalui MAA daripada diselesaikan melalui pengadilan Mahkamah Syari'ah, seperti masalah sengketa

16. https://id.m.wikipedia.org/wiki/Aceh dilihat pada hari Jumat tanggal 4 Maret 2018, Pukul 19.45 WIB

17. Peraturan Daerah Nomor 7 Tahun 2000 tentang Penyelenggaraan Kehidupan Adat

18. Wawancara dengan Tgk. Yusdedi Ketua majelis Adat Aceh Tanggal 28 Maret 2018, pada Pukul 11.10 WIB 
warisan, karena menurut mereka lebih sesuai dengan rasa keadilan yang tumbuh dalam masyarakat dan tergolong lebih efektif. ${ }^{19}$

Indonesia sudah ada Kompilasi Hukum Islam, namun kebanyakan masyarakat Aceh masih tetap menyelesaikan pembagian warisan melalui Majelis Adat Aceh, karena menurut mereka tergolong lebih efektif dan sesuai dengan hukum Islam yang bermashab syafi'i bahkan hukum adat itu lebih dipatuhi oleh karena adanya orang yang mengingatkan, meski tidak tertulis. ${ }^{20}$ Namun masih banyaknya kendala yang dihadapi oleh MAA ditingkat Gampong, dimana mereka masih memiliki kekurangan tenaga kerja dalam menyelesaikan persoalan yang berkaitan dengan warisan serta kurangnya fasilitas yang belum memadai.

Hukum adat yang tumbuh dalam masyarakat Aceh di Tempok Tengoh dalam perkara warisan selalu di upayakan dengan berbagai cara agar dapat diproses dalam bentuk perdamaian/Hukom Suloh. Ini menunjukkan bahwa setiap persoalan warisan yang timbul dalam masyarakat dapat diselesaikan tanpa terganggunya keseimbangan sosial masyarakat dan terjaganya keharmonisan. Kerena itu, setiap persoalan yang timbul dalam masyarakat untuk tahap pertama tetap diselesaikan ditingkat gampong dan pada tahap kedua dapat naik banding ke tingkat Mukim, ini sesuai dengan Mou antara Gubernur Aceh, Polda Aceh dan MAA, yang mana memberikan kesempatan kepada majelis adat untuk menyelesaikan terlebih dahulu masalah-masalah sosial yang timbul dalam masyarakat di peradilan adat Gampong dan Mukim, bila tidak tercapainya perdamaian maka selanjutnya dilimpahkan ke Pengadilan.

Masyarakat Tempok Teungoh juga menyebut peradilan perdamaian dengan sebutan Hukom Suloh. Adapun faktor-faktor yang membuat masyarakat lebih menggunakan Hukom Suloh melalui Majelis Adat Aceh sebagai berikut : ${ }^{21}$

1. Mampu menjaga harga diri, derajat keluarga, reputasi, nama baik keluarga dan lain sebaginya diantara kedua belah pihak, dikarenakan masyarakat lebih mengutamakan keakraban, kerukunan, keseimbangan dan cinta damai.

2. Tidak ada yang menang dan yang kalah.

3. Proses yang singkat dan tidak rumit.

4. Putusan yang mengandung banyak kebijakan, kearifan, serta sesuai dengan rasa keadilan yang tumbuh dalam masyarakat.

5. Bersedia datang ke rumah yang bersengketa.

6. Biaya yang dikeluarkan sangat murah.

7. Hemat waktu dan tenaga.

8. Keputusan Bertahan sepanjang waktu

Majelis Adat Aceh Lhokseumawe khususnya Kecamatan Tempok Tengoh sangat berperan penting dalam kehidupan adat masyarakat, bahwa masyarakat masih sangat percaya kepada Majelis Adat untuk menangani sengketa-sengketa yang timbul dalam masyarakat. Saat ini sengketa yang paling banyak timbul

19. Hasil Wawancara dengan Teungku Adlan, Keuchik Tempok Teungoh pada tanggal 31 Maret 2018, pukul 09.45 WIB

20. Mahadi, laporan hasil pengkajian bidang hukum adat, BPHN, 1980, hal. 61.

21. Wawancara dengan Tengku Yusdedi, Ketua Majelis Adat Aceh, Tanggal 29 Maret 2018, Pukul 10.14 WIB. 
dalam masyarakat adalah masalah faraid atau warisan, jumlahnya hampir mencapai 85\% sengketa yang ditangani Gampong-Gampong hanya mengenai faraid, bahkan jika permasalahan tersebut tidak dapat diselesaikan di tingkat Gampong akan diserahkan ke tingkat Mukim. ${ }^{22}$

Peran Majelis Adat Aceh di tingkat Gampong atau Mukim Tempok Tengoh adalah sebagai mediator dan fasilitator dalam menyelesaikan sengketa warisan. Dalam setiap proses penyelesaian sengketa atau perselisihan menurut hukum adat di tingkat Gampong, maka yang berperan di dalamnya adalah geuchik dan teungku iтиет meunasah, mediasi dilakukan di tempat atau rumah orang yang meninggal atau almarhum atau pewaris biasanya disebut rumoh tuha. Geuchik dan Teungku mempunyai tugas ganda yaitu sebagai mediator sekaligus sebagai komunikator dan disisi lain sebagai pemimpin musyawarah adat dan juru runding. Geuchik juga bertindak sebagai hakim atau juri damai. ${ }^{23}$

Penyelesaian tingkat Gampong atau Mukim, setiap keputusan yang disepakati dalam hal warisan selalu berdasarkan suatu analisa dan pertimbangan yang mencakup seluruh aspek dalam keluarga dan mempunyai kekuatan hukum mengikat semua pihak, karena setiap pertimbangan selalu memperhatikan normanorma yang hidup dan tumbuh dalam masyarakat yang merujuk pada Al-Qur'an dan Hadist dikarenakan hukum adat harus tunduk pada hukum Islam. ${ }^{24}$

Semua perkara yang timbul dalam masyarakat Aceh dapat diartikan bahwa penyelesaiannya semua melalui Hukum Suloh. Hukum waris adat merupakan hukum yang memuat garis-garis ketentuan tentang sistem dan azas-azas hukum waris, tentang harta warisan, pewaris dan ahli waris serta cara bagaimana warisan itu dialihkan penguasaan dan pemilikannya dari pewaris kepada ahli waris yang sesuai dengan ketentuan hukum Islam. Hukum adat harus tunduk dan sesuai dengan ketentuan hukum Islam. ${ }^{25}$

Setiap penegakan hukum ada tiga unsur yang harus dicapai, yaitu unsur kepastian hukum, kemanfaatan dan keadilan. ${ }^{26}$ Setiap pihak yang merasa dirugikan mulanya akan melapor kepada para perangkat Gampong, Geuchik atau Teungku Imeum atau kepada kepala lorong/kepala dusun, dengan menerima pengaduan dari pihak keluarga. Dapat dipahami bahwa semua yang melibatkan perangkat desa berarti telah muncul sengketa diantara mereka, bila tidak biasanya mereka hanya melibatkan para orang alim/Teungku atau sanak saudara yang pandai dalam ilmu faraid. Oleh karena itu kemudian Geuchik melakukan analisa perkara tesebut untuk penyelesaiaan sengketa bersamaan dengan Teungku Imeum dan kepala lorong, Tuha Peut bertugas hanya mengetahui laporan saja. ${ }^{27}$

22. Hasil Wawancara dengan Ibu Latifah Sekretaris Majelis Adat Aceh, Tanggal 29 Maret 2018, Pukul 13.00 WIB.

23. Isa Sulaiman dan T. Syamsuddin, Pedoman Adat Aceh:Peradilan Adat dan Hukum Adat, Lembaga Kebudayaan dan Adat Aceh (LAKA), 2002, hal. 7.

24. Wawancara dengan Teungku Adlan, Keuchik Tempok Teungoh tanggal 30 Maret 2018, pukul 09.23 WIB

25. Wawancara dengan Teungku Adlan, Keuchik Tempok Teungoh tanggal 30 Maret 2018, pukul 09.47 WIB

26. Ibid.

27. Wawancara dengan Teungku Adlan, Keuchik Tempok Teungoh tanggal 30 Maret 2018, pukul 09.47 WIB 
Berdasarkan beberapa kasus yang diselesaikan oleh mahkamah syari'ah maupun majelis adat aceh, terlihat bahwa dalam pembagian waris tanah yang dilakukan oleh majelis adat aceh hanya berdasarkan dengan hukum adat dan tidak berlandaskan hukum islam sebagaimana yang telah dijelaskan pada pasal 99 Undang-Undang Nomor 11 tahun 2006 tentang Pemerintah Aceh bahwa dalam pembinaan kehidupan adat dan adat istiadat dilakukan dengan perkembangan keistimewaan dan kekuasaan aceh yang berlandaskan pada nilai-nilai syari'at islam dan dilaksanakan oleh wali nanggroe.

Dalam hal ini peran MAA menjalankan tugasnya tidak hanya berdasarkan hukum adat akan tetapi juga harus berdasarkan hukum islam dan harus berdasarkan asas-asas hukum adat aceh yang berlaku. Berdasarkan teori receptie in complexu menjelaskan bahwa hukum islam dipandang sebagai hukum yang hidup dan berlaku bagi umat islam, akan tetapi dalam pelaksanaannya MAA khususnya dikecamatan tempuk teungoh dalam menyelesaikan pembagian waris tidak berdasarkan hukum islam, akan tetapi hanya berdasarkan hukum adat saja.

Berdasarkan hasil penelitian diketahui bahwa dalam masyarakat Kota Lhokseumawe khususnya Tempok Teungoh sudah memilih suatu kebiasaan menyelesaikan berbagai persoalan dan sengketa termasuk dalam hal ini sengketa pembagian warisan. Seperti diketahui, persoalan tentang harta warisan menjadi persoalan utama di kalangan masyarakat yang terkena. Hal ini terjadi karena kehidupan masyarakat tidak terlepas dari kehidupan adat dan adat merupakan sumber hukum yang terlebih dahulu diterapkan di Aceh. Meskipun jarang terdapat hasil peraturan yang tertulis, pelaksanaan adat di Aceh selalu beriringan dengan prinsip syariat Islam. ${ }^{28}$

Dalam praktiknya penyelesaian sengketa waris tanah dalam peradilan adat diselesaikan secara bertahap, di mana sengketa yang terjadi diselesaikan terlebih dahulu dalam keluarga, apabila tidak dapat diselesaikan maka akan dibawa pada penyelesaian secara adat di gampong dimana perangkat gampong yang menjadi penengah. Apabila ditelaah mengenai proses dilakukannya penyelesaian sengketa pembagian warisan dengan melibatkan keuchik di tingkat gampong, Keuchik dalam kedudukannya sebagai pimpinan pemerintahan gampong adalah sebagai negosiator atau mediator yang dengan sendirinya harus memiliki kemampuan menjalankan proses negosiasi dan mediasi atau penengah dari para pihak yang terlibat menyelesaikan sengketa warisan.

Dalam hal ini keuchik bersama dengan perangkat gampong berwenang :

1. Mengontrol proses dan menegaskan aturan dasar proses negoisasi dan mediasi sejak awal sampai akhir. Dalam hal ini keuchik bersama dengan perangkat gampong menfasilitasi pertemuan para pihak guna membicarakan semua kemungkinan untuk mewujudkan kesepakatan dan membantu menawarkan sejumlah solusi dalam penyelesaian sengketa.

2. Mempertahankan mekanisme dan momentum damai dalam negosiasi. Keuchik bersama dengan perangkat gampong berwenang menjaga dan mempertahankan struktur dan memomentum dalam negosiasi, dimana para

28. Wawancara dengan Tengku Yusdedi, Ketua Majelis Adat Aceh Kota Lhokseumawe, Tanggal 1 April 2018 Pukul 10.13 WIB 
pihak diberikan kesempatan melakukan pembicaraan dan tawar menawar dalam menyelesaikan sengketa pembagian warisan dimaksud dengan mengemukakan alibi masing-masing.

3. Mengakhiri proses bilamana mediasi tidak menemui hasil yang diharapkan. Dalam proses mediasi para pihak yang bersengketa sering merasa sulit berdiskusi secara terbuka. Mereka mempertahankan prinsip secara ketat dan kaku terutama saat negosiasi. Ketika mediator melihat para pihak tidak mungkin lagi diajak kompromi dalam negosiasi, maka mediator berwenang menghentikan proses mediasi.

Pilihan penyelesaian sengketa tanah dengan melibatkan keuchik dalam bentuk mediasi merupakan teknik atau mekanisme penyelesaian sengketa yang mendapat perhatian serta diminati dengan beberapa alasan yang melatarbelakanginya sebagai berikut: ${ }^{29}$

1) Perlunya menyediakan mekanisme penyelesaian sengketa yang lebih fleksibel dan responsif bagi kebutuhan para pihak yang bersengketa.

2) Untuk memperkuat keterlibatan masyarakat dalam proses penyelesaian sengketa.

3) Memperluas akses mencapai atau mewujudkan keadilan sehingga setiap sengketa yang memiliki ciri-ciri tersendiri terkadang tidak sesuai dengan bentuk penyelesaian yang satu akan cocok dengan bentuk penyelesaian yang lain dan para pihak dapat memilih mekanisme penyelesaian sengketa yang terbaik dan sesuai dan sengketa yang dipersengketakan.

Berdasarkan uraian di atas jelas bahwa hasil dari proses penyelesaian sengketa tanah yang diselesaiakan oleh MAA secara adat pada tingkat gampong di Tempuk Teungoh Kota Lhokseumawe dituangkan dalam suatu kesepakatan damai yang merupakan hasil rumusan dari para pihak beserta keuchik dan perangkat gampong.

Pada penyelesaian yang dilakukan oleh Gampong di Tempuk Tengoh masih adanya putusan MAA yang tidak memiliki kekuatan hukum yang mengikat, maka para pihak ada yang menerima putusan dari MAA dan tidak menerima putusan MAA dikarenakan bahwa di pengadilan harga yang dibayar untukmenyelesaikan suatu perkara sampai tuntas cukup tinggi atau mahal. Harga inimencakup sejumlah uang yang harus di bayar, waktu yang harus disediakan, tenagayang harus di keluarkan, dan psikis yang harus di tanggung.

Semantara itu keadilan yang didapatkan ternyata acapkali pula tidak sesuai denganrasa keadilan yang tumbuh dalam masyarakat, keadilan yang ada hanya keadilanmenurut undang-undang atau keadilan secara yuridis, atau keadilan menurut hakimyang mengemukakan bagaimana undang-undang atau pasal-pasal dari undang-undangitu di terapkan. ${ }^{30}$ Namun masyarakat walaupun bukti tertulis merupakan bukti yang diakui secara hukum kesepakatan secara lisan tetap menjadi pegangan utama, di mana sebagian masyarakat masih memegang teguh pernyataan yang diucapkan dalam suatu kesepakatan atau perjanjian melalui ijab

29. Wawancara Ibu Latifah, Sekretaris Majelis Adat Aceh Kota Lhokseumawe, pada tanggal 2 April 2018, Pukul 10.15 WIB

30. Hasil Wawancara dengan Mukhtar, masyarakat aceh Kota Lhokseumawe, pada tanggal 7 April 2018, Pukul 11.15 WIB 
kabul antara para pihak sebagai bukti terkuat karena diikuti oleh adanya penyataan sumpah dari para pihak yang bersengketa.

Setiap penegakan hukum ada tiga unsur yang harus dicapai, yaitu unsurkepastian hukum, kemanfaatan dan keadilan. ${ }^{31}$ Bila ada kelompok legalitas yang menganggap hukum perundang-undangan jauh lebih penting dari hukum adat, maka kelompok tersebut lebih mengutamakan unsur kemanfaatan terlebih dahulu, kemudian diikuti unsur keadilan dan kepastian hukum. Sebenarnya hukum ada demi kebahagiaan masyarakat, oleh karenanya penegakan hukum harus benar-benar nyata memberikan manfaat dan kegunaan bagi masyarakat. Penegakan hukum jangan sampai timbul keresahan dan terpecah-belah masyarakat. ${ }^{32}$

Dengan kata lain MAA juga tidak memiliki kewenangan memutuskan dalam sengketa waris tanah dan menetapkan siapa yang jadi pewaris, namun pada sebagian masyarakat pernyataan secara lisan tentang ijab kabul untuk penyelesaian sengketa juga dipandang sebagai bukti layaknya bukti tertulis.

Kesepakatan yang dibuat secara tertulis dan ditandatangani oleh para pihak sebagai bukti dari adanya kesepakatan dalam penyelesaian sengketa dengan menuangkan berbagai hal yang menyangkut objek sengketa waris baik berupa tanah maupun harta benda lainnya. Kekuatan hukum atas kesepakatan tersebut merupakan alat bukti yang kuat dan diakui oleh para pihak layaknya suatu putusan hakim dan berlaku serta mengikat para pihak yang bersengketa.

Beberapa tanggung jawab para pemangku adat untuk memastikan bahwa prinsip-prinsip dalam peradilan adat dipegang teguh dalam setiap proses penyelesaian sengketa secara adat. ${ }^{33}$ Adanya pengakuan dan efektifnya berlaku suatu putusan lembaga ada juga disebabkan karena tokoh para anggota masyarakat menaruh kepercayaan kepada para pemimpin adat untuk menyelesaikan perselisihan secara adil dan damai. Akan tetapi dalam penyelesaian sengketa terlihat bahwa para pihak juga setelah dilakukan putusan oleh MAA tidak menimbulkan hubungan baik dengan para pihak.

Pembagian warisan tidak dilakukan sesuai dengan ketentuan yang berlaku, padahal dalam pembagian warisan telah ada ketentuan, baik itu menurut hukum adat, hukum perdata maupun menurut hukum Islam. Ketentuan pembagian warisan tersebut bertujuan positif untuk menyelamatkan umat dari perbuatan tercela, yakni mengambil, menguasai dan memakan harta benda milik orang lain secara tidak sah atau tidak sesuai dengan ketentuan. Hukum Islam menghendaki pembagian harta warisan kepada ahli waris sesuai dengan porsi masing-masing.

Dalam hal terjadinya sengketa warisan termasuk dalam hukum adat diakibatkan tidak terpenuhinya hak-hak sebagian dari ahli waris. Ahli waris dimaksud adalah sekumpulan orang atau kerabat yang ada hubungan kekeluargaan dengan orang yang meninggal dunia dan berhak mewarisi atau

31. Sudikno Mertokusumo, 2010, Mengenal Hukum, Penerbit: Universitas Atma Jaya, Yogyakarta, hal. 122.

32. Ibid

33. Wawancara dengan Tengku Yusdedi, Ketua Majelis Adat Aceh Kota Lhokseumawe, Tanggal 1 April 2018 Pukul 10.26 WIB 
menerima harta peninggalan yang ditinggal oleh seseorang (pewaris). ${ }^{34}$ Sedangkan Pasal 171 huruf (c) Kompilasi Hukum Islam menjelaskan yang dimaksud dengan ahli waris adalah orang pada saat meninggal dunia mempunyai hubungan darah atau hubungan perkawinan dengan pewaris, beragama Islam dan tidak terhalang karena hukum untuk menjadi ahli waris.

Dalam proses tersebut, tokoh adat dan alim ulama akan membantu para pihak untuk mencapai kesepakatan bersama, dimana kedua belah pihak akan mencari jalan keluar yang dihasilkan lewat perdamaian (mediasi). Sebagian besar sengketa di Kecamatan Tempok Teungoh penyelesaiannya jarang dilakukan melalui Mahkamah Syari'ah karena orang aceh memiliki prinsip tersendiri terhadap permasalahan yang diselesaikan melalui Peradilan formal,

"Pantang Pedeung Muelinteung Sarong, Pantang Rincoeng Meulinteung Mata, Pantang Ureung Di Te'oeh Kawoem, Pantang Hukum Taba Bak Meja." yang artinya Pantang pedang melewati sarung, pantang rencong mata ke atas,Pantang orang di ketahui segala perbuatan kaum atau keturunannya, pantanghukum di bawa ke meja hijau atau pengadilan." 35

Pada dasarnya hukum waris merupakan salah satu dasar syari'at dalam agama Islam. Namun pada perkembangannya (salah satu karena mayoritas penduduk Indonesia adalah Muslim), syari'at ini lama-kelamaan menjadi adat dalam sebuah keluarga dihampir seluruh daerah Indonesia. ${ }^{36}$

B. Penerapan Putusan yang di Ambil Oleh Majelis Adat Aceh Bagi Para Pihak yang Bersengketa di Kecamatan Tempok Tengoh Kota Lhokseumawe

Penerapan putusan dari hukum adat dalam masyarakat Tempok Teungoh ini mempunyai nilai lebih setelah adanya buku tentang pedoman peradilan adat di Aceh, telah banyak mengarahkan pemangku adat baik di tingkat Gampong atau di tingkat Mukim untuk mencatat atau mengadministrasikan semua perkara yang ada, dengan dilengkapi dengan form-form pelaporan dan penyelesaian kasus. ${ }^{37}$

Dari sisi administrasi ini menunjukkan menambah bobot dari putusan peradilan adat, dengan mudah diawasi dan memberikan salinan kepada para pihak, lembaga Mukim dan juga kepada kepolisian agar mereka mengetahui bahwa suatu perkara telah diselesaikan melalui Adat Gampong. Pencapaian tujuan dalam menyelesaikan sengketa sesuai dengan asas rukun, patut, dan laras. ${ }^{38}$

Mediasi menjadi cara yang tepat untuk menemukan perdamaian. Jika tidak bisa diselesaikan dan akhirnya harus dibawa ke pengadilan umum atau syari'ah, maka ini akan membuat malu para pihak keluarga, sebab perkaranya sudah

34. Idris Ramulyo, , 2003, Perbandingan Hukum Kewarisan Islam dengan Kewarisan Hukum Perdata Sinar Grafika, Jakarta, hal. 83

35. Wawancara dengan Tengku Yusdedi, Ketua Majelis Adat Aceh Kota Lhokseumawe, Tanggal 5 April 2018 Pukul 10.08 WIB

36. Wawancara dengan Tengku Yusdedi, Ketua Majelis Adat Aceh Kota Lhokseumawe, Tanggal 1 April 2018 Pukul 10.05 WIB

37. Tim penyusun, Pedoman Peradilan Adat Di Aceh, edisi ke-2, Majelis Adat Aceh, 2012, hal. 42.

38. Moh. Koesnoe, Catatan-Catatan Terhadap Hukum Adat Dewasa Ini, Airlangga University Press 1979 
diketahui oleh umum, maka para keluarga banyak yang menempuh jalur ditingkat gampong. Dengan demikian penyelesaian di tingkat Gampong itu masih mempunyai kedudukan hukum yang kuat, karena hingga saat ini badan peradilan dimaksud belum pernah dicabut. ${ }^{39}$

Didalam peradilan adat Aceh untuk menyelesaikan sengketa mempunyai istilah tersendiri yaitu Uleu Beumatee, Ranteng bek patah yang dapat dapat diterjemahkan bahwa dalam memukul ular hingga mati namun ranting yang digunakan untuk memukul ular tersebut jangan sampai patah. Ini mempunyai makna bahwa setiap perselisihan harus dapat diselesaikan, namun keharmonisan harus tetap terjaga dan jangan sampai dengan penyelesaian perselisihan dapat menimbulkan dendam dan permusuhan. ${ }^{40}$

Penerapan hukum itu berhasil apabila hukum itu mencapai tujuan, artinya hukum tersebut benar-benar berlaku dan berfungsi. ${ }^{41}$ Hukum dapat dikatakan berhasil dalam penerapannya jika terdapat dampak hukum yang positif, berarti hukum tersebut mencapai sasarannya yaitu adil dan seimbang menurut hukum Islam.

Secara umum, penerapan hukum diartikan sebagai keberhasilan dalam pencapaian target atau tujuan yang telah ditetapkan. Pencapaian ini dikarenakan terus dilaksanakan oleh para pihak dan setiap keputusan yang diambil oleh peradilan adat memenuhi kaidah-kaidah yang tumbuh dalam masyarakat, sehingga kasus yang telah diselesaikan secara adat tidak ada yang melahirkan keributan dikemudian hari dan tidak lagi diajukan ke pengadilan. Dalam hal ini, derajat kepatuhan hukum masyarakat menjadi salah satu parameter tentang efektif atau tidaknya hukum itu diberlakukan.

Dengan demikian, penyelesaian masalah waris dengan menggunanakan prinsip kesepatakan ini bukanlah sesuatu yang tidak mempunyai pijakan doktrinal dalam sistem hukum Islam.

"Abu Zahrah, seorang ulama usul fiqh kenamaan yang dikutip Satria Efendi Zein, juga menegaskan bahwa Kemungkinan pembagian warisan secara kekeluargaan. Namun demikian, persyaratan paling utama yang harus dipenuhi adalah adanya kesepakatan dan kerelaan dari para ahli waris. Lebih jauh, ahli waris tersebut juga dapat menggugurkan haknya untuk tidak mendapatkan hak waris dan memberikannya kepada ahli waris yang lain. Sebaliknya, bila para ahli waris, atau di antara ahli waris tidak setuju atau tidak rela harta warisan tersebut dibagi secara kekeluargaan, maka sistem pembagiannya dilakukan sesuai aturan faraid yang telah dijelaskan oleh AlQur'an dan Sunnah, atau dalam konteks Indonesia, sesuai peraturan perundang-undangan yang telah menjelaskan hal itu." ${ }^{42}$

39. T. Ibrahim El Hakimy, Hakim Perdamian Desa Sebagai Ujung Tombak Pencipta Kerukunan Dan Ketertiban Masyrakata, LAKA NAD, Banda Aceh 2001, hal. 28. WIB

40. wawancara dengan Tengku Rasyid,Tokoh Adat Aceh, Pada tanggal 31 Maret pukul 13.35

41. Soerjono Soekanto, Masalah Kedudukan dan Peranan Hukum Adat, Academica, Jakarta 1979, hal. 5.

42. Satria Effendi Zein, Problematika Hukum Keluarga Islam Kontemporer: Analisis Yurisprudensi dengan Pendekatan Ushuliyah, Kencana, Jakarta: 2004. 
Berdasarkan hasil penelitian diketahui bahwa dalam masyarakat Kota Lhokseumawe khususnya Tempok Teungoh sudah memilih suatu kebiasaan menyelesaikan berbagai persoalan dan sengketa termasuk dalam hal ini sengketa pembagian warisan. Seperti diketahui, persoalan tentang harta warisan menjadi persoalan utama di kalangan masyarakat yang terkena. Hal ini terjadi karena kehidupan masyarakat tidak terlepas dari kehidupan adat dan adat merupakan sumber hukum yang terlebih dahulu diterapkan di Aceh. Meskipun jarang terdapat hasil peraturan yang tertulis, pelaksanaan adat di Aceh selalu beriringan dengan prinsip syariat Islam. ${ }^{43}$

Dalam praktik penyelesaian sengketa adat dalam peradilan adat diselesaikan secara bertahap, di mana sengketa yang terjadi diselesaikan terlebih dahulu dalam keluarga, apabila tidak dapat diselesaikan maka akan dibawa pada penyelesaian secara adat di gampong dimana perangkat gampong yang menjadi penengah.

Apabila ditelaah mengenai proses dilakukannya penyelesaian sengketa pembagian warisan dengan melibatkan keuchik di tingkat gampong Keuchik dalam kedudukannya sebagai pimpinan pemerintahan gampong adalah sebagai negosiator atau mediator yang dengan sendirinya harus memiliki kemampuan menjalankan proses negosiasi dan mediasi atau penengah dari para pihak yang terlibat menyelesaikan sengketa warisan.

Pilihan penyelesaian sengketa tanah dengan melibatkan keuchik dalam bentuk mediasi merupakan teknik atau mekanisme penyelesaian sengketa yang mendapat perhatian serta diminati dengan beberapa alasan yang melatarbelakanginya sebagai berikut: ${ }^{44}$

1) Perlunya menyediakan mekanisme penyelesaian sengketa yang lebih fleksibel dan responsif bagi kebutuhan para pihak yang bersengketa.

2) Untuk memperkuat keterlibatan masyarakat dalam proses penyelesaian sengketa.

3) Memperluas akses mencapai atau mewujudkan keadilan sehingga setiap sengketa yang memiliki ciri-ciri tersendiri terkadang tidak sesuai dengan bentuk penyelesaian yang satu akan cocok dengan bentuk penyelesaian yang lain dan para pihak dapat memilih mekanisme penyelesaian sengketa yang terbaik dan sesuai dan sengketa yang dipersengketakan.

Berdasarkan uraian di atas jelaslah bahwa hasil dari proses penyelesaian sengketa tanah secara adat pada tingkat gampong di Tempuk Teungoh Kota Lhokseumawe dituangkan dalam suatu kesepakatan damai yang merupakan hasil rumusan dari para pihak beserta keuchik dan perangkat gampong.

Beberapa tanggung jawab para pemangku adat untuk memastikan bahwa prinsip-prinsip dalam peradilan adat dipegang teguh dalam setiap proses penyelesaian sengketa secara adat. ${ }^{45}$

43. Wawancara dengan Tengku Yusdedi, Ketua Majelis Adat Aceh Kota Lhokseumawe, Tanggal 1 April 2018 Pukul 10.13 WIB

44. Wawancara Ibu Latifah, Sekretaris Majelis Adat Aceh Kota Lhokseumawe, pada tanggal 2 April 2018, Pukul 10.15 WIB

45 .Hasil Wawancara dengan Tengku Yusdedi, Ketua Majelis Adat Aceh Kota Lhokseumawe, Tanggal 1 April 2018 Pukul 10.26 WIB 
Adapun bentuk tanggung jawab yang menjadi jaminan penerapan berlakukanya putusan lembaga adat adalah:

1. Melaksanakan proses peradilan adat Para pemangku adat bertanggung jawab terhadap setiap tahapan peradilan adat, mulai dari menerima laporan, memeriksa duduk persoalan sampai pada tahap rapat persiapan sidang akhir dan sampai dengan pemberian putusan peradilan adat.

2. Memutuskan dengan adil Para pemangku adat harus memastikan bahwa setiap keputusan-keputusan yang diambil dari sebuah proses paradilan adat sedapat mungkin memenuhi rasa keadilan para pihak yang bersengketa, dimana keputusan yang diambil berdasarkan hasil proses pembuktian dan musyawarah, bukan berdasarkan kepentingan salah satu pihak yang bersengketa.

3. Melindungi hak-hak para pihak yang bersengketa Para pemangku adat bertanggung jawab terhadap pemenuhan hak-hak para pihak yang bersengketa mulai dari proses menerima laporan, memeriksa duduk persoalan, proses persidangan sampai pada tahap pelaksanaan putusan-putusan di persidangan.

4. Mencatat Proses dan Keputusan Peradilan Setiap proses dan keputusankeputusan yang telah diambil harus dicatat secara akurat dalam dokumen administrasi peradilan adat.

5. Mengarsipkan berkas perkara Berkas perkara termasuk surat pejanjian yang berisi keputusan-keputusan adat harus disimpan atau diarsipkan secara aman oleh pemangku adat, hal ini penting dilakukan untuk menjamin dan mempelancar proses peradilan bagi kasus-kasus lain serta kasus yang sama terulang kembali, sehingga pemangku adat mempunyai referensi dalam melakukan proses peradilan dan mengambil keputusan-keputusan sengketa adat.

Adanya pengakuan dan efektifnya berlaku suatu putusan lembaga ada juga disebabkan karena tokoh para anggota masyarakat menaruh kepercayaan kepada para pemimpin adat untuk menyelesaikan perselisihan secara adil dan damai. Akan tetapi dalam penyelesaian sengketa terlihat bahwa sebagian para pihak juga setelah dilakukan oleh MAA tidak menimbulkan hubungan baik dengan para pihak.

Sejauh ini bukan berarti pemangku adat tidak pernah mencatat setiapperistiwa yang ada, akan tetapi tidak dengan catatan yang rapi,karena merekamengira cukup dengan ingatan yang kuat dan dengan secarik kertas sebagaiadministrasi, memang ini tidak sebagaimana yang diharapkan oleh LSM asing selakupemberi pelatihan yang ingin meneliti tentang adat. Layaknya hukum adat yangtumbuh dalam masyarakat mempunyai khas tersendiri yaitu tidak tertulis akan tetapitetap terus berjalan tanpa adanya administrasi, itu disebabkan oleh norma-normasosial yang tumbuh dalam masyarakat begitu kental dan menganggap administrasi tidak terlalu penting dan seakan merumitkan.

Begitupun dalam penereapan putusan sengketa warisan dalam peradilan adat,tidak mempunyai catatan yang istimewa yang berupa form-form pengaduan dan form putusan, namun pencatatannya menunjukkan bukti sangat kuat. Mereka menganggap putusan peradilan adat merupakan hasil dari mediasi dalam rangka tercapainya perdamaian, setelah perdamaian terjadi maka tercapainya maksud dan 
tujuan tidakharus dengan form-form. Perdamaian dan keseimbangan sosial merupakan titik akhirdari Peradilan Adat.

Secara yuridis penyelesaian sengketa secara damai melalui fungsionaris adat telah dibakukan dalam beberapa peraturan Daerah Provinsi Nanggroe Aceh Darussalam. Secara formal pada awalnya dibakukan dalam Peraturan Daerah Nomor 7 Tahun 2000 tentang Penyelenggaraan Kehidupan Adat yang sekarang telah diganti dengan Qanun Nomor 9 Tahun 2008 tentang Pembinaan Kehidupan Adat dan Adat Istiadat yang menghendaki bahwa hendaknya sengketa-sengketa yang terjadi dalam masyarakat lebih dahulu secara adat pada tingkat gampong dan mukim. Apa yang diatur dalam Peraturan Daerah tersebut merupakan tindakan kongkrit yang dialakukan Pemerintah Aceh pada waktu itu untuk menjalankan kewenangan pelaksanaan keistimewaan Aceh, khususnya keistimewaan di bidang adat istiadat.

Putusan peradilan adat adalah putusan damai dan oleh karena itu putusan boleh diterima dan boleh juga tidak diterima oleh salah satu pihak atau kedua belah pihak. Apabila putusan itu telah diterima oleh para pihak maka putusan itu dapat segera dilaksanakan. Namun demikian apabila suatu putusan telah diterima, menimbulkan kewajiban untuk dilaksanakan.

Apabila pihak yang telah menerima putusan, kemudian tidak melaksanakan putusan tersebut, meskipun telah diminta untuk dilaksanakan, maka peradilan dapat menjatuhkan putusan boikot dalam kehidupan bermasyarakat terhadap pihak yang melanggar putusan yang telah diterimanya. Boikot tersebut dalam bahasa daerah disebut boikot keureuja udep dan keureujamate. Terhadap pelanggar putusan peradilan dihukum boikot oleh seluruh masyarakat lingkungannya terhadp semua hal, baik menyangkut persoalan hidup maupun persoalan mati. Orang yang dihukum boikot dianggap seperti tidak ada lagi di kampung bersangkutan. ${ }^{46}$

Segala perselisihan dan persengketaan yang telah didamaikan oleh MAA dalam suatu rapat adat bersifat mengikat pihak-pihak yang berselisih/bersengketa. Para pihak yang tidak mengindahkan keputusan adat ia akan dikenakan sanksi adat yang lebih berat oleh karena merusak kesepakatan dan mengganggu keseimbangan yang hidup dalam masyarakat.

Keputusan yang telah dikeluarkan oleh para perangkat adat gampong sebenarnya tidak boleh lagi dilanggar oleh para pihak karena dasar keputusan tersebut adalah berdasarkan mediasi dan mufakat kedua belah pihak yang disaksikan oleh perangkat MAA, dan dikeluarkan berita acara atau surat keputusan MAA yang ditandatangani oleh kedua belah pihak, kepada para pihak yang bertikai biasanya kalau kasus-kasus tersebut seperti perkelahian yang menyebabkan keluar darah dari salah satu pihak, maka dibuat upacara peusijuk disamping penyelesaian secara damai.

46. Hasil Wawancara dengan Latifah, Sekretaris Majelis Adat Aceh masyarakat Kota Lhokseumawe, Tanggal 8 April 2018 Pukul 10.46 WIB 


\section{KESIMPULAN}

1. Peran Majelis Adat Aceh ditingkat Gampong atau Mukim Tempok Teungoh adalah sebagai mediator dan juga fasilitator dalam menyelesaikan sengketa warisan. Dalam setiap proses penyelesaian sengketa atau perselisihan menurut hukum adat di tingkat Gampong atau Mukim setiap keputusan yang disepakati dalam hal warisan selalu berdasarkan suatu analisa dan pertimbangan yang mencakup seluruh aspek dalam keluarga dan seharusnya memiliki kekuatan hukum yang mengikat juga menghasilkan kesepakatan damai, akan tetapi peran MAA ini masih banyak belum berjalan dengan baik, dikarenakan dengan putusan yang dihasilkan oleh MAA masih banyak masyarakat yang mengeluhkan dan tidak mendapatkan keadilan dan adanya hasil dari keputusan MAA ini mengakibatkan keributan antara para pihak dikarenakan keputusan yang digunakan MAA tidak dengan berdasarkan syari'at islam, hanya berdasarkan keputusan adat.

2. Penerapan putusan yang diambil oleh Majelis Adat Aceh Lhokseumawe bagi para pihak yang bersengketa belum memiliki kekuatan hukum yang mengikat, karena putusan yang dikeluarkan oleh MAA masih bisa diajukan ke Mahkamah Syariah bagi para pihak yang ingin mendapatkan keadilan yang seadil-adilnya. Dalam hal ini keputusan MAA didukung dengan peraturan-peraturan aceh yang berlaku.

\section{SARAN}

1. Diharapkan kepada Masyarakat Aceh Kota Lhokseumawe agar selalu menjunjung tinggi nilai-nilai adat dan agar dapat lebih memilih peradilan alternatif seperti peradilan adat di Gampong dan Mukim dalam menyelesaikan setiap masalah, guna tercapainya keharmonisan antar sesama.

2. Kepada Majelis Adat Aceh disarankan untuk lebih memperbaiki sistem administrasi, dan diharapkan agar peradilan Majelis Adat Aceh dan peradilan adat lainnya dapat menjalankan tata cara peradilan adat seperti layaknya peradilan nasional dalam kontek adat dengan menjalankan lebih baik lagi setiap ketentuan tertulis dari buku pedoman peradilan adat di Aceh.

\section{REFERENSI}

\section{A. Buku-Buku}

Abdurrahaman, 2009, Peradilan Adat di Aceh sebagai Sarana Kerukunan Masyarakat, Majelis Adat Aceh (MAA), Banda Aceh.

Achmad Ali, 2002, Menguak Tabir Hukum (Suatu Kajian Filosofis dan Sosiologis), Toko Gunung Agung, Jakarta.

Abu Achmadi dan Cholid Narbuko, 2001, Metodologi Penelitian, Bumi Aksara, Jakarta.

Al Yasa' Abu Bakar, 2005, Bunga Rampai Pelaksanaan Syariat Islam (Pendukung Qanun Pelaksanaan Syariat Islam), Dinas Syariat Islam Prov. NAD, Banda Aceh.

Anonimos, 2003, Sistem Peradilan Adat dan Lokal di Indonesia; Peluang dan Tantangan, (t.tp.: Aliansi Masyarakat Adat Nusantara (AMAN) dengan Dukungan dari Patnership for Governance Reform.

Bushar Muhammad, 2006, Pokok-pokok Hukum Adat Pradnya Paramita, Jakarta.

Dean G. Pruitt dan Jeffrey Z. Rubin, 2004, Konflik Sosial, Pustaka Pelajar, Yogyakarta . 
Departemen Pendidikan dan Kebudayaan, 1989, Kamus Besar Bahasa Indonesia, Balai Pustaka, Jakarta.

Dominikus, R, 2010, Filsafat Hukum Mencari: Memahami dan Memahami Hukum, Yogyakarta: Laksbang Pressindo.

Effendi Perangin, 2014, Hukum Waris, PT RajaGarafindo Persada, Jakarta.

Eman Suparman, 2007, Hukum Waris Indonesia, Refika Aditama, Bandung.

Fatchurahman, 1981, Ilmu Waris, Al-Ma'arif, Bandung.

Hasan Alwi dkk, 2008, Kamus Besar Bahasa Indonesia.

Hiksyani Nurkhadijah, 2013, Sistem Pembagian Harta Warisan, Skripsi, Universitas Hasanudin, Makassar.

Hilman Hadikusuma, 1993 Hukum Waris Adat, Cipta Aditya Bhakti Bandung.

Indroharto, 1993, Usaha Memahami Undang-Undang tentang Peradilan Tata Usaha Negara (I), Jakarta, Sinar Harapan.

Ismail Badruzzaman, 2008, Pedoman Peradilan Adat di Aceh, Banda Aceh.

Kamal Hidjaz, 2010, Efektivitas Penyelenggaraan Kewenangan Dalam Sistem Pemerintahan Daerah Di Indonesia. Pustaka Refleksi, Makasar.

Lawrence M. Friedman, 2009, Sistem Hukum Perspektif Ilmu Sosial (A Legal Sistem A Sosial Science Perspektive), diterjemahkan oleh M. Khozim. Nusa Media, Bandung.

Lukman Hakim, 2011, Kewenangan Organ Negara Dalam Penyelenggaraan Pemerintahan, Malang.

M. Hasballah Thaib, 2009, Ilmu Hukum Waris Islam, Medan.

Nasution, 1996, Metode Research (Penelitian Ilmiah), Bumi Aksara : Jakarta.

Nurmayani, 2009, Hukum Administrasi Daerah. Universitas Lampung Bandar lampung.

Lexy J. Moleong, 2007, Metodologi Penelitian Kualitatif, Remaja Rosdakarya, Bandung.

M. Solly Lubis, 1994, Filsafat Ilmu dan Penelitian, Mandar Maju: Bandung.

Peter, M.M, 2008, Pengantar Ilmu Hukum, Kencana, Jakarta.

Prodjojo Hamidjojo, 2000, Hukum Waris Indonesia, Stensil, Jakarta.

Riduan Syahrani, 1999, Rangkuman Intisari Ilmu Hukum, Citra Aditya Bakti, Bandung.

Rifqah Sesarina, 2013, Analisis Yuridis Putusan Lembaga Adat Aceh Dalam Penyelesaian Sengketa Pembagian WarisanDi Kota Banda Aceh, Banda Aceh.

Ridwan HR, 2013, Hukum Administrasi Negara. PT Raja Grafindo Persada. Jakarta.

Riduan Syahrani, 1999, Rangkuman Intisari Ilmu Hukum, Citra Aditya Bakti, Bandung.

Ronny Hanitijo Soemitro, 1988, Metodologi Penelitian Hukum dan Jurumetri, Ghalia Indonesia, Jakarta.

Salim HS dan Elies Septiana Nurbani, 2013, Penerapan Teori Pada Penelitian Tesis dan Desertasi, Raja Grafindo Persada, Jakarta.

Soebakti, Poesponoto, 1960, Asas-asas dan Susunan Hukum Adat, Pradnya Paramita, Jakarta.

Soerjono Soekanto,1990, Pengantar Penelitian Hukum, Universitas Indonesia Press, Jakarta.

Soerjono Soekanto, Soleman B. Taneko, 2003, Hukum Adat Indonesia, PT. Raja Grafindo Persada, Jakarta.

Soerojo Wigjodipoero, 1995, Pengantar dan Asas-Asas Hukum Adat, Gunung Agung, Jakarta.

Soepomo, 1993, Bab-Bab tentang Hukum Adat, Pradnya Paramita, Jakarta.

Sri Mamuji dan Soerjono Soekanto, 2011, "Penelitian Hukum Normatif, Suatu Tinjauan Singkat”, Rajawali Press, Jakarta. 
Syahrizal, 2004, Hukum Adat dan hukum Islam di Indonesia, Nadiya Foundation Nanggroe Aceh, Banda Aceh.

Syahrizal Abbas, 2009, Mediasi Dalam hukum syariah, hukum adat, dan hukum nasional, Kencana Prenada Media Group, Jakarta.

Takdir, Rahmadi, 2010, Mediasi, Penyelesaian Sengketa Melalui Pendekatan Mufakat, PT. Raja Grafindo Persada, Jakarta.

Velerine J.L.K, Mediasi(Tinjauan dari egi Antropologi Hukum), dalam Antropologi Hukum, 2001, Sebuah Bunga Rampai oleh T.O. Ihromi, Yayasan Obor, Jakarta.

Wirjono Projodikoro, 1991, Hukum Warisan di Indonesia. Sumur, Bandung.

Zainuddin Ali, 2008, Pelaksanaan Hukum Waris di Indonesia, Sinar Grafika, Jakarta

B. Peraturan Perundang-Undangan

Undang-Undang Dasar 1945

Undang-Undang Nomor 11 Tahun 1999 tentang Penyelenggaraan Keistimewaan Aceh

Qanun Provinsi Aceh Nomor 10 Tahun 2008 tentang Lembaga Adat

\section{Jurnal dan Website}

Mahadi, 1980, Laporan hasil pengkajian bidang hukum adat, BPHN.

Fauza Andriyadi, "Reposisi Majelis Adat Aceh dalam tata pemerintahan aceh pasca qanun nomor 10 tahun 2008", Jurnal Agama dan Hak Asasi Manusia, Vol. 5 No. I, November 2015, Aceh.

Mohd. Zaim Irsyad, Struktur Dan Lembaga Adat Di Aceh, http://misteraim.blogspot. com/html, Diakses 17 Februari 2017.

Rahmat Fitrah, https://media.neliti.com/media/publications/164922-ID-efektifitaspenyelesaian-sengketa-warisan.pdf, diakses tanggal 28 Februari 2017.

Wikipedia pada http://firsta tesismanajemenkonflik.blogspot.co.id/2013/07/demokrasi-deliberasi-apaitu.html deliberatif adalah sebuah organisasi yang secara bersama membuat keputusan setelah debat dan diskusi. Diakses Pada tanggal 29 Januari 2018.

Wikipedia pada http://aceh.tribunnews.com/2013/05/30/menakar-keistimewaanaceh, dilihat pada tanggal 28 Maret 2018. 